\title{
A Legal Inquiry into the Proliferation and Control of Small Arms in Nigeria
}

\author{
Pontian Okoli
}

School of Law, University of Dundee, UK

\begin{abstract}
The continual state of insecurity in Nigeria for several decades can be traced to a number of factors, including ethnic militias and religious fundamentalism. This article examines the extent to which such retrogressive phenomena are caused or fuelled by the proliferation of small arms in Nigeria. It examines the legal regime on small arms, non-legal but relevant societal issues and police powers as they concern the control of small arms proliferation in Nigeria. It argues that the extant legal regime is not robust enough to support any sustainable progress in this area. Also, it concludes that apart from a critical police overhaul and necessary municipal legislative action as influenced by international legal developments, practical policies and economic empowerment must be in place with a view to attaining sustainable development in the area of small arms control.
\end{abstract}

Keywords: Small arms, violent crimes, religious fundamentalism, ethnic militias, police powers, proliferation, economic empowerment, Firearms Act, Firearms Regulations, lethality.

\section{THE EVOLUTION OF SMALL ARMS PROLIFERA- TION IN NIGERIA}

In Nigeria, the evolution of small arms has been tied to the emergence of widespread armed robbery which incidence has witnessed a steady and alarming increase over the years since 1970 (Nwabueze, 1993: 32). The term "small arms" (rather than "firearms" as used in Nigerian laws) is used because of its international appeal in current lingo. In this article, both terms are inevitably used interchangeably. It has been postulated that at the end of the 30-month civil war in January 1970, there was a considerable number of arms and ammunition scattered around the country, and a large number of young people, demobilised from the army with no gainful employment, for whom armed robbery provided a ready and easy means of making quick money. This trajectory was supported with so much money from Nigeria's new-found oil wealth which came in 1973. The reckless spending and mismanagement of the oil wealth by the military government and the resultant inflation and unemployment had the effect of pushing many more people to join the ranks of armed robbers (Nwabueze, 1993: 32).

It is therefore apposite to note the need to factor in "non-coercive inducements" in any serious and sustained effort to control the proliferation of small arms. Such "non-coercive inducements" have been stated to include economic empowerment and voluntary disarmament schemes (see generally, mdtf.undp.org/document/download/4666 accessed

*Address correspondence to this author at the School of Law, University of Dundee, UK; E-mail: pontian19@yahoo.com
January 15,2014$)$. It is however contended that voluntary disarmament schemes, albeit non-coercive, cannot be correctly classified as preventive as they occur after proliferation and therefore a reactive rather than proactive measure. Furthermore, great care must be taken in such schemes so as not to legitimise illegality and institutionalise a culture of impunity and opportunistic pecuniary or other gain. Curiously, a learned commentator had long ago proposed that easy access to guns for the citizenry may be the answer to combating armed robbers since many of the victims would then acquire capacity to procure a defence (Adinkrah, 1986: 71). So, in modern history, apart from the civil war factor, which has been supported elsewhere (Vines, 2005: 358), armed robbers and the military played a pioneering role in the proliferation of small arms in Nigeria (Vines, 2005: 358).

Most recently, with the militancy arising out of the perceived neglect of the Niger Delta despite the resultant environmental damage from activities of petroleum companies and the rise in the activities of the dreaded Boko Haram Islamic militancy sect (see Oyebode, 2012), the need to put a stop to the availability of small arms to unauthourised persons has become particularly imminent.

\section{Definition of Small Arms}

The term in question is given a special consideration, because it is at the core of this article. Apart from that, the meaning attributed to the term is arguably a basic consideration with respect to proliferation and control. The term "control" is generally used to have equal effect or weight as "possession". For example, section 3 of the Firearms Act Chapter 
F28, LFN, 2004 provides that "No person shall have in his possession or under his control any firearm of one of the categories specified in Part I of the Schedule to this Act...except in accordance with a licence granted by the President acting in his discretion". Relevant provisions include section 4 (personal firearms), section 5 (muzzle-loading firearms which may be prohibited except under licence, section 8 (ammunition), section 26 (prohibition of shortening of smooth-bore firearms) and section 27 (penalties). See further section 3(1) of the Robbery and Firearms (Special Provisions Act), Chapter R11, LFN 2004. The relevant pieces of Nigerian legislation, the Firearms Act of 1958 and Firearms Regulations (See generally Chapter F28, LFN, 2004), do not use the term "small arms". Instead, in section 2 of the Firearms Act, the term "firearms" is used and means:

\section{Any lethal barrelled weapon of any description from which any shot, bullet or other missile can be discharged, and includes a prohibited firearm, a personal firearm and a muzzle-loading firearm of any of the categories referred to in parts $I$, II and III respectively of the schedule hereto, and any component part of any such firearm.}

However, it seems that this definition does not adequately reflect the special attention which prevention of small arms proliferation requires. For example, it would mean that rocket weapons, bombs, grenades artillery and gas diffusing projectiles would be placed on the same level with pistols. See Part I of the Schedule to the Firearms Act. It may, however, also be persuasively argued that some of these weapons (or sometimes at least locally made weapons with similar effects) are increasingly being used by militia groups and fundamentalist sects such as Boko Haram. In any case, the fact is that the definition of "firearms" attempts, if unintentionally, to factor in some elements of small arms and light weapons. Expectedly, it fails to do so definitively especially in the case of the latter. Whilst the threats of various sorts of lethal violence are real, it may be a distraction to make detailed laws within this context regarding rocket weapons which are obviously not easy to conceal, for example.

In Olatunji v State [2003] 14 NWLR (Pt. 839) 138 at pp 165-166, the Nigerian Supreme Court reproduced the definition of "firearm" under section 2 of the Firearms Act. In the instant case, the appellant was charged with the unlawful possession of a hand grenade. One of the issues that arose for determination at the Supreme Court was "whether, in order to prove that a hand grenade is a firearm, the evidence of an expert is necessary". The court simply referred to the definition of firearm given in section 2 of the Firearms Act (Chapter 146 LFN 1990, now Chapter F28 LFN 2004) which clearly showed that a grenade is a prohibited firearm and a lethal weapon within the meaning of the Firearms Act and one would need no evidence of an expert to prove it as it is intrinsic in the Act itself. Of course, it would have been outside the purview of the court and amounted to an academic exercise somewhat for the court to go into a jurisprudential analysis as to whether the classification is ideal.

The term "small arms" is not found anywhere in the Criminal Code Act, but the term "firearms" is defined in section 403B of the Criminal Code Act of 1916: "For the purposes of section 402, 403 and 403A- firearms includes any canon, gun, flint-lock gun, pistol, explosive or ammunition or other firearm, whether whole or in detached pieces". It appears that this definition is not radically different from that of the Firearms Act, especially in view of "...ammunition or other firearm" in this definition.

The definition of firearms in section 11(1) of the Robbery and Firearms Act of 1984 curiously and ironically appears to be a little closer to what a contemporary idea of what a less wieldy definition would be. It "....includes any canon, gun, rifle, machinegun, cap-gun, flint-lock gun, revolver, pistol, explosive or other firearms, whether in whole or in detached pieces".

The definition of "firearms" in the United Kingdom legal regime is traditionally similar to that of Nigeria but has obviously been improved upon over time. It means:

A lethal barrelled weapon of any
description from which any shot, bullet or
other missile can be discharged, and
includes any prohibited weapon, whether
it is such a lethal weapon or not, any
component part of such a lethal or
prohibited weapon, and any accessory to
any such weapon designed or adapted to
diminish the noise or flash caused by firing
the weapon.

See also generally, paragraph 2.3 of the Firearms Law, Guidance to the Police 2002 (see 
http://www.dyfed-powys.police.uk/archive/documents/

FirearmsLaw.pdf accessed January 12, 2014). It is contended that "...and any accessory to any such weapon designed or adapted to diminish the noise or flash caused by firing the weapon" be added to the definition of firearms in the Nigerian context as is the case with the UK legislation, considering the danger such accessories pose in that they bolster the confidence of the bearers of easily concealable small arms fitted with the said accessory as to their ability to use the weapons without risk of detection.

Although cases hardly come up on the interpretation of the Firearms Act in Nigeria, it is a fact that lethality is a complex issue and only the courts are able to determine such definitively. This reality is exemplified by cases such as Moore $v$ Gooderham [1960] 3 All E.R. 575. In the UK, the Forensic Service Provider would usually be able to advise on lethality, which fact is supported by the guidelines of the Crown Prosecution Service (see http://www.cps.gov.uk/ legal/d_to_g/firearms/ accessed January 12, 2014). "Barrelled" is a question of mixed law and fact as seen in $R v$ Singh (1989) Crim. L.R. 724 CA, where there was an evidential dispute as to whether a fire launcher was barrelled.

Internationally, it does not appear that there is a consensus on the correct definition of small arms. Arguably, the best UN attempt at having an official definition of small arms is contained in the International Instrument to Enable States to Identify and Trace, in a Timely and Reliable Manner, Illicit Small Arms and Light Weapons (A/60/88) adopted by the UN General Assembly on 8 December 2005: any man-portable lethal weapon that expels or launches, is designed to expel or launch or may be readily converted to expel or launch a shot, bullet or projectile by the action of an explosive (see http://www.un.org/events/smallarms 2006/faq.html accessed January 13, 2014). Whether or not this meaning is acceptable, it is hardly useful in this research as its scope is restricted to small arms although it is also conceded that small arms and light weapons are often lumped together. In any case the fact is that the same source notes that small arms and light weapons are also differentiated on the bases of type and effect, as well as the number of people required to operate. Whilst small arms would be operated by one person, light weapons are usually designed for use by two or three persons.

In any case, there has been a steady gravitation towards compartmentalisation. Most relevant materials tend to use "small arms" and "firearms" interchangeably - arguably because Nigerian laws generally use "firearms" whilst "small arms (and light weapons)" is more internationally used. More so, small arms can generally be subsumed under "firearms". Indeed, it is arguably safe to state that whilst all small arms are firearms, not all firearms are small arms.

\section{THE PROLIFERATION OF SMALL ARMS AS A PERENNIAL PROBLEM}

The proliferation of small arms has continually been a source of great concern. Some factors have facilitated this problem and they include the following:

They are cheap to obtain: this is because they are usually not sophisticated as to warrant too much expenditure (see http://www.maginternational.org/news/reducing-the-threat-of-smallarms-and-light-weapons/ accessed January 29, 2013).

(2) They are plentiful in supply: this is because basic knowledge of the rules of demand and supply aid us in the understanding that cheap items are more easily accessible (see http://www.maginternational.org/news/reducing-the-threat-of-smallarms-and-light-weapons/ accessed 29 January 29, 2013).

(3) They are simple to use: this is partly, if not entirely because small arms are not so complex as to require expert knowledge or great strength (see http://www.maginternational.org/news/ reducing-the-threat-of-small-arms-and-lightweapons/ accessed January 29, 2013). This is illustrated by the reality that children sometimes use such weapons. Children are increasingly becoming the direct victims and casualties due to small arms violence. 20 children were among the 27 killed in the Connecticut school shooting of 2012, said to be the "third major gun attack in the US in 2012" (See http://www.bbc.co.uk/news/ world-us-canada-20730717 (accessed January $15,2014)$.

(4) They are easily concealed: the small size of such arms is apparently the underlying reason here. Pushed to its logical conclusion, it means that such weapons could escape the notice of even vigilant police (see http://www.un.org/disarmament/ convarms/SALW/ accessed January 13 2014).

(5) They are portable: there has been a trend towards miniaturisation in weapons 
development. The result is that many weapons previously thought of as "medium" weapons (such as the explosive missile projector) are now effectively considered as individual "light weapon" to be classified with more traditional portable small arms (see http://www.un.org/ disarmament/convarms/SALW/ accessed January 13,2014$)$.

(6) Economic hardship fuels frustration, which is a fertile ground for provocation. The spate of crime has equally been tied to Nigeria's economic adversity (Atta, 1997: 96). However, rather than merely being seen as a result of poverty, control of small arms proliferation is also persuasively argued to be key to reducing poverty (see http://www.undp.org/content/undp/en/home/pres scenter/articles/2012/09/07/preventing-illegalflow-of-guns-is-key-to-reducing-poverty-/ accessed January 14 2014).

(7) Criminal manifestations in Nigeria such as armed robbery have only got worse over time. The police, in spite of whatever efforts made have not been able to have a firm grip on crime. There is no solution yet to continual clashes between communities, which are arguably fuelled by the availability and access to small arms. It is even more disturbing that there is a clear need to curb the misuse of firearms by the police. Therefore violence is not only often exacerbated by the availability and access to small arms but also sometimes caused by the incompetence of the police in reasonably reducing the possession of small arms after conflicts and not being proactive enough to control the circulation of small arms even before conflicts especially in areas with a clear history of communal conflicts.

(8) Nigerian statutes concerning small arms appear to be inadequate (and certainly poorly enforced) in view of modern complexities.

The aforementioned factors have in their various ways contributed to the perennial dimension of the proliferation in question. The factors are not exhaustive but those mentioned are directly relevant to Nigeria and therefore, adequately suffice for the present purpose.

\section{ANALYSES OF RELEVANT STATUTES}

The following Nigerian statutes will be considered: the Firearms Act, the Firearms Regulations, the
Criminal Code Act, and the Police Act. These are made with a view to bringing to the fore some of their inadequacies or grey areas and to distil how much contribution such defects have made to the proliferation of small arms.

It is instructive to note that the Firearms Act, like most Nigerian statutes, is apparently ossified. For example, between 1990 Like the extant Laws of the Federation 2004, the Laws of the Federation 1999 was essentially a mere compilation of hitherto scattered laws in Nigeria rather than any substantive input. It has been noted that it was "last reviewed in 1995" (Wakil, 2005: 54). However, a comparison of the 1990 LFN and the 2004 LFN reveals no significant substantive difference. For example, between 1990 and 2004, there was no amendment to the Firearms Act, except that some sections were deleted, the effects of which are functionally inconsequential. Since 2004, there has been no amendment at all, although, the reality is that there has arguably been no substantive amendment for nearly half a century. The Firearms Act was enacted in 1959. This is certainly not the case in more progressive countries. The legislative dynamism of the UK, for example, can be gleaned from the following: the 1920 Firearms Act, the 1937 Firearms Act, the 1967 Criminal Justice Act, the 1968 Firearms Act, the Firearms Amendment Act of 1968, the 1997 Firearms (Amendment) (No. 2) Act and the 2006 Violent Act Reduction Act.

Certain inadequacies are discovered when modern realities are juxtaposed with the definition of firearms. The definition of "firearms" under the Act appears unwieldy. Elements of the classification as a term are also unnecessarily loose. For example, it is not made clear in the interpretation section or any other section, that a weapon is lethal if it is capable, irrespective of the maker's intentions, of causing injury.

Apparently, section 26 is the only provision that contemplates a reconstruction of arms to suit portability and consequently, proliferation. The section prohibits shortening smooth-bore firearms, but it is too restrictive. There is no contemplation of other more clever ways of converting otherwise harmless contraptions. In Cafferata v Wilson [1936] 3 All ER 149, a dummy revolver was considered capable of conversion by drilling into the weapon and therefore, capable of killing a man of a range of five feet. Similar considerations were made in Moore $v$ Gooderham [1960] 3All ER 575 and $R v$ Thorpe [1987] 85 Cr. App. Rep. 107. 
The question of conversion was further considered in Grace v DPP (1989) Crim. LR 365, where it was held that in determining whether a particular weapon is a "firearm", there are two issues:

Whether it is a weapon from which any shot can be discharged or whether it can be adapted so as to discharge any such missile;

2) If so, whether it is a lethal barrelled weapon. The earlier cases do not establish that a particular weapon is, as a matter of law, a lethal weapon.

Again, under section 5 of the Firearms Act, the prohibition of muzzle-loading firearms is left to the discretion of the Commissioner of Police of a State with the consent of the State except under licence. Section 6 which contains provisions concerning not granting licences and permits as of right, subjects its provisions "to the provisions of subsection 5 of section 5 of this Act" which subsection is obviously lacking as the subsections of section 5 end in subsection 4 . This is a significant (typographical) error since a comprehensive interpretation of sections 5 and 6 , which both crucially concern licences and permits, is not possible.

The minimum age for applying for a licence or permit is 17, as provided in section 6(2)(a) of Firearms Act which is in accord with the qualification for enlistment in the Nigeria Police Force provided in section 72(2)(a) of the Police Act of 1943 (Subsidiary Legislation), Chapter P19, LFN 2004. The age requirement in the latter case (of the Force) is more understandable because one is compelled to develop better responsibility whereas in the case of the former (mere application for a licence or permit), such a person may well be in high school with all the effects of peer pressure.

Under section 7(2) of the Firearms Act, the owner of a firearm has 14 days to notify the authority who has issued the licence of loss, theft or destruction of such firearm - this is arguably too long for notification especially as being proactive can be a useful tool in the control of small arms. Section 7 generally shares a similar problem with section 10(3). Under this section, a registered firearms dealer has 7 days to report loss, theft or destruction.

Under section 6(2)(e) of the Firearms Act, an applicant would not be granted a licence or permit if "...during five years (he) has been convicted of an offence involving violence or the threat of violence". It is contended that this restriction is unnecessary especially as Nigeria hardly has a culture of keeping proper records. More so, many cases which should be prosecuted do not get to court and when they do, often last for several years due to lack of diligent prosecution (and may thus end in the accused being discharged) or institutional delays.

Part $\mathrm{V}$ of the Firearms Act reveals several grey areas. For example, a practical implication of section 19 is that an individual having a licence or permit can import a muzzle loading dane gun as part of his personal effects. This is generally unacceptable especially now that proliferation of small arms has become a national (and global) issue. A British arms dealer, Gary Hyde, was convicted and jailed for 7 years by a London court in 2012 for shipping thousands of guns and ammunition from China to Nigeria without a licence. The delivery in 2007 included " 40,000 AK-47 assault rifles, 30,000 rifles, 10,000 pistols and 32,000 rounds of ammunition" (see http://www.bbc.co.uk/news/ uk-england-humber-20611395 accessed January 17, 2014)

Whatever qualifications exist to this reality are mere diction niceties with little constructive function. This is not to suggest that such is technically abhorrent. However, the current realities of poor internal regulation must be factored in and as such, it is arguably more pragmatic to prevent small arms from coming in at all where possible rather than wait for a person to comply with internal regulations like completing "a prescribed form of declaration that his destination is within Nigeria but is in excess of twenty miles from the place of importation and that he will surrender such firearm or ammunition to a specified authority or at a public armoury at or near his destination in accordance with such declaration and with the terms or a permit for temporary possession thereof to be issued by the Inspector-General of Police" as provided in section 19(b) of the Firearms Act. Movement of arms will be examined later.

It would be useful to factor in the connection between crime and punishment. The penalties for offences under relevant laws (except perhaps the Economic and Financial Crimes Commission (Establishment) Act 2004, a recent enactment which is better known for its anti-corruption provisions but which also contains provisions regarding anti-terrorism) are generally reflective of a weak approach to the proliferation of small arms. Section 27 of the Firearms Act, which generally provides for penalties, thus requires close attention. For example, the practical 
implication of section $27(1)$ (b)(iv) is that a violation of section 19 (which restricts the importation of personal firearms) merely attracts a term not exceeding five years imprisonment, is arguably inappropriate or inadequate, especially in a country where there is so much desperation as exemplified by concealing small arms in bags of rice (see 2013. Sunday Sun, February 4. (Lagos), p1). This is questionable especially when one considers how many people who may have died from such illegal deals. Also, it seems ridiculous that one thousand naira (roughly equivalent to $\$ 7$ or $£ 4$ ) is still a fine-in which case that may be all the punishment meted out for violating section 5(3) which restricts the possession or control of a muzzle-loading firearm within a specified area, which is provided in 27(1) (c) (i) of the Firearms Act. One way of working around such ridiculous fines that is often brought about by inflation and depreciation of the Nigerian currency, is to empower the relevant minister to issue regulations in that regard as may be necessary when the need arises to avoid having to go through the entire cumbersome legislative process. Although the President may amend (by order) under the extant law, it is with respect to "any part of the Schedule to this Act" rather than the substantive provisions in the light of section 33 of the Firearms Act.

The provisions of section 428 of the Criminal Code Act are perhaps better imagined. The implication of the section is that any person who has unlawful possession of arms belonging to the Nigerian armed forces is liable to a fine of 40 naira (less than half of $\$ 1 \cup S$ ) and to pay double of the value of all or any of the several articles which he shall be possessed of. It is contended that this undermines any reasonable effort at combating the scourge of proliferation of small arms. The recommendation made earlier with respect to ridiculous fines and punishment will also apply here. Section 427 of the Criminal Code Act which would have been better, provides: "Any person who receives anything which has been obtained by means of any act constituting a felony or misdemeanor...knowing the same to have been so obtained is guilty of a felony." A couple of these provisions contradict those of more progressive societies, in spite of the fact that such progressive societies do not necessarily battle with the self-implosive phenomena of ethnic militias and religious fundamentalism, as well as their negative contributions to the proliferation of small arms.

Under section 6(1) of the Firearms Regulations, it is provided that "within fourteen days of the withdrawal of any firearm from a registered dealer's or public armoury, the person withdrawing the same shall produce the firearm and the licence therefor to a licensing authority". It is submitted that 14 days is excessive. Under sections 12 (application for registration as firearms dealer), and 20 (withdrawal of firearms and ammunition from public armoury) sections such as section 14 which provide for the appointment of watchmen by the Inspector-General of Police may practically involve police officers even though it obviously concerns "any registered dealer's armoury" unlike section 20 which appertains to "the officer in charge of a public armoury". The reason is that it is common to see police officers attached to some individuals and companies on a 24-hour basis- it would therefore be unjustifiable to hire civilians to guard armouries when an already understaffed police force has spread its scarce personnel around individuals and the private sector.

Police officers may have to play crucial roles in relation to possible sale or transfer, but should such police officers be run-of-the-mill type? This question is necessary in view of the fact that police officers sometimes give out guns illegally even when they are not in charge of any armoury. This is illustrated by the Apo Killings case, where a witness said that the police gave him guns to place by the victims (see 2005. The Guardian. June 23, (Lagos), p1). The abuse of firearms by the Nigerian police is a fact. Policemen have been accused of firing at and killing innocent commuters for failing to pay illegal toll, extra-judicially murdering suspects, and worse, armed robbers have been known to have sourced arms from the police (Open Society Institute: 2010). It is submitted that the provision of a police guard if at all, as provided in section 25 of the Firearms Regulations, as an escort of consignments of firearms is not realistic.

The exemption of air guns is provided for under section 51 of the Firearms Regulations. That is, they are not subject to any of the provisions of the Firearms Act or the Firearms Regulations. It is difficult to appreciate the rationale behind this apparently deliberate lacuna. First, air guns are certainly (personal) firearms as provided in Part II of the Schedule to the Firearms Act Second, air guns have been held capable if misused, of causing injury from which death might result. Moore $v$ Gooderham [1960] 3All ER 575.

Under the Criminal Code Act, the only relevant provision is section 403B which for the purposes of sections 402, 403 and 403, "firearms" includes any 
canon, gun, flint-lock gun, revolver, pistol, explosive or other firearm whether whole or in detached pieces. Curiously, air guns and air pistols are classified as "offensive weapons". Whereas section 51 of the Firearms Regulations has a discriminatory application to air rifles and air pistols on the one hand, and air guns on the other-the latter not being subject to any provisions of the Act or Regulations. Yet, air guns, airrifles or air-pistols are clearly classified as firearms under the Firearms Act as provided in Part II of the Schedule to the Firearms Act. This confusion and inconsistency, like some others already noted, can only accentuate proliferation.

The Criminal Procedure Act of 1945 Chapter C41, LFN 2004 makes no reference to firearms or even small arms whilst the Police Act makes reference to firearms in relation to the provision of arms for the Force. However, the issue of inconsistency earlier observed in the Criminal Code Act apparently extends to the judicial interpretation of lethality and how the proliferation of small arms may be encouraged by a rather naïve perception of imitation small arms.

The question of lethality as considered by the Nigerian courts is important in order to further highlight the havoc which unhindered access to small arms poses, especially to the safety of the citizenry. A couple of comments will help to understand the problems which relevant statutes are fraught with in dealing with lethality. In Nwachukwu v State [1985] 3NWLR (Pt 11) 218 at 225, the Court of Appeal, per Nnaemeka-Agu JCA, held that "a toy-gun is not normally made or adapted for causing injury to the person and is not capable of being used as an offensive weapon but a play thing for children. I am satisfied that it is not an offensive weapon." Placing the statement in a factual context will help. In this case, the appellant had "brought out a pistol and pointed it at him (a complainant), and demanded from him the bag he was carrying; or to lose his life". This happened around 9:30pm. On further appeal, the Supreme Court in Nwachukwu $v$ State [1986] 2NWLR (Pt 25) 765 considered the effect of a toy-gun only with respect to the offence of robbery since "toy-gun" didn't fall within the meaning of "offensive weapon" or "firearm". As such the elements of a charge of simple robbery were made out but not robbery involving a threat of violence or aggravated robbery.

Whilst it is conceded that "a conviction can lie in respect of such lesser offence either on a trial of the offence charged or by the accused pleading guilty to such lesser offence, although he was not charged with it" (see The Queen v Nwaogwugwu [1962] 1All NLR 294), it is contended that the Supreme Court ought to have evaluated and disapproved of the statement that a toy gun is "not capable of being used as an offensive weapon but a play thing for children". This, it is further contended, is different from merely positing, as the Court of Appeal apparently or ostensibly set out to do, that a toy gun is not an offensive weapon or firearm within the meaning of the Robbery and Firearms (Special Provisions) Act No 47 of 1970" (see the Court of Appeal's summary of the appellant's submission at $p$ 222). It is submitted that the (possible) effect of the toy gun should have been a defining issue. If pointing a real gun (albeit without any shot fired) would be an offence of robbery with threatened violence or aggravated/armed robbery, it should be no different if a toy gun was used as the effect on people, most of whom have never in fact seen a real gun, would be the same. Indeed, in the case in question, 9:30pm must have been very dark. The Court of Appeal was apparently too quick to offer a mechanical interpretation of the Act without significant effort at applying practical logic. The end result may be precluding the misuse of other weapons which though lethal may likely not pass the test of firearms as defined by the various Nigerian enactments.

Although the Supreme Court, based on provisions of the Robbery and Firearms Act, took a similar decision in Ikemson \& Ors $v$ State [1989] 3NWLR (Pt 110) 455 at 477 , more recent Supreme Court decisions seem to take a more realistic and pragmatic view of the matter. For example, in Debbie $v$ The State S.C 103/2005, delivered on 9 March 2007 (also similar to Tanko v State [2009] 4NWLR (Pt 1131) 430 at 453 SC), the Supreme Court noted, per Katsina-Alu JSC, that, "whether it was a real pistol that was pointed at PW1 is immaterial. What is material is that either an actual pistol or what looked like an actual pistol was used to threaten her which induced fear in her. It is the use made of an object and the manner it is made use of that qualifies it to be an offensive weapon". It is important to note that the meaning of "offensive weapon" does not literally include toy guns, so the philosophy underlying that realistic dictum ought to apply to firearms or small arms as well. A significant problem is that such more recent cases apparently do not refer to or consider or attempt to distinguish Nwachukwu $v$ State, which is itself, a Supreme Court decision. Some other progressive jurisdictions have clear and stringent provisions concerning imitation 
firearms and in the United Kingdom, for example, the accused persons in Nwachukwu $v$ State may have been sentenced to 10 years imprisonment for possessing an imitation firearm. This is reflected in section 2.22 of the UK Firearms Law (Guidance to the Police 2002). See http://www.dyfed-powys.police.uk/ archive/documents/FirearmsLaw.pdf

(accessed January 15, 2014).

\section{CONNECTING THE PROLIFERATION OF SMALL ARMS WITH VIOLENT CRIMES}

Efforts have been made to consider the evolution of small arms in Nigeria, the proliferation of small arms as a perennial problem, and various definitions of small arms. In addition, the analyses of various statutes have revealed the inadequacies and grey areas of such enactments.

It would be useful to address some specifics with particular reference to how the proliferation of small arms connects with violent crimes in the context of relevant data. It is however difficult to refrain from coming to the conclusion that proper and reliable statistics are still mere aspirations. This is because in the "10 point Programme of Action" by a former Inspector-General of Police, Sunday Ehindero, part of the plans included "improving criminal data base" and "reogranising and strengthening the Research and Planning department in order to ensure that reliable criminal statistics are produced and disseminated." Also, another plan is the "effective control of firearms". It may be inferred from the Programme of Action that at least by implication, such reliable criminal statistics do not presently exist (see http://www.thenationonlineng. net/archive2/tblnews_Detail.php?id=19206 accessed January 16, 2014). It is important to emphasise that it would not be enough to rely on some random search on the Internet if the Nigeria Police Force concedes that there is generally no reliable database.

Nevertheless, desperate efforts have been made to find some data, however probably imperfect. This is contained in the 2005 vision statement for the Police Service presented by a former Inspector-General of Police, Tafa Balogun. This was made during a world press briefing on December 28, 2004, at Force Headquarters, Louis Edet House, Abuja. Balogun stated very clearly, the direct connection between the proliferation of small arms and the rate of violent crime. He observed that "our experience has shown that the higher the proliferation of illegal arms in the public, the higher the wave of violent crime in the country" (see
2005. The Guardian. January 23, (Lagos), p 21). Elsewhere, the police chief identified the proliferation of arms as "one of the major factors behind violent crime in Nigeria" (Alemika, Etannibi EO. and Chukwuma, Innocent C (eds): 2004.

It is a reality that Nigeria has no culture of keeping statistics properly - and when attempts are made to keep some semblance of statistics they are often haphazardly done. Or not at all- the website http://www.nigeriapolice.org accessed January 29, 2013) has not been helpful. However, as far back as 2005, the Inspector-General of Police stated that "our experience has shown that the higher the proliferation of illegal arms in the public, the higher the wave of the violent crime in the country". The statistics he provided at the time were obviously supportive of his extrapolation (see 2005. The Guardian. January 23, 2005. (Lagos), p 21). Efforts were made to compile murders from 1999 to 2004. 48 of such murders were stated in outline form, most of which were caused by gunmen. 928 firearms were recovered in 2000, 1,013 in 2001; 3, 150 in 2002; 3,451 in 2003; 5,405 in 2004. However, there have been more recent indications that the Nigerian police tend to prefer an image-laundering exercise than to accept realities (and as such, it may be imprudent to rely on more recent police data). An example is the interrogation of a Chairman of the National Human Rights Commission for observing that the Nigeria Police Force "executes well over 2,500 detainees summarily every year" (see http:// dailytimes.com.ng/article/police-interrogate-humanrights-chief accessed January 28, 2013). Amnesty International described it as "police intimidation" and that "the police ought to be spending their time and energy investigating allegations of extrajudicial executions...rather than harassing the National Human Rights Commission" (see http://www.foxnews.com/ world/2012/04/16/nigeria-police-want-to-interrogaterights-leader/ accessed January 20, 2014).

The press has been most helpful in compiling data that are at least public record. A most recent effort compiled assassinations from 1999 to 2012, including that of a sitting attorney-general and minister of justice in 2001, the Chairman of the Onitsha branch of the Nigerian Bar Association with his wife in 2002, a Senior Advocate of Nigeria in 2003 (equivalent of a Queen's Counsel in the UK), a Lagos State governorship aspirant in 2006, an Ogun State governorship candidate in 2007, a Borno State governorship candidate in 2011, and two serving senators in 2012 (see 2013. TELL Magazine, January 7, pp. 50-51). The 
claim by the Inspector-General of Police in 2004 that the police for example "through meticulous investigation exposed the killers of Chief Bola Ige, former Minister of Justice in December, 2001" (among others) was apparently an image-laundering move at the time as the same police observe that the case is still open. See the interview with Frank Mba, chief superintendent of police and force deputy public relations officer-TELL magazine, above at $p 48$.

\section{THE SUSTAINED RISE OF ETHNIC MILITIAS AND RELIGIOUS FUNDAMENTALISM}

There will be an examination of the sustained rise of ethnic militias and religious fundamentalism vis-à-vis inchoate offences. The examination is made in the light of the following:

a) Analysis of the powers of preventive action.

b) Analysis of the powers of entry and search.

c) Analysis of the powers to stop, inspect and detain vehicles.

The aforementioned analyses are in relation to small arms. There are so many happenings in Nigeria that necessitate an examination of the various sources and means of transporting small arms, with a view to evaluating the inadequacies of legal provisions in this regard.

The existence of various forms of the aforementioned subtopic is as old as humanity. With the passage of time, there have been a lot of dynamics in nomenclature, but essentially, the very nature of both has not changed. Global examples are quite handy, with each region of the world having, or having had a fair share. In Nigeria, ethnic militias include Niger Delta People Volunteer Force (NDPVF), Movement for the Survival of Ogoni People (MOSOP), Movement for the Actualisation of the Sovereign State of Biafra (MASSOB), Odua People's Congress (OPC), and Arewa People's Congress (APC). Other emergent ethnic militias are the Federated Niger Delta ljaw Community (FNDIC) and the Movement for the Emancipation of the Niger Delta (MEND).

In Nigeria, NDPVF and MASSOB especially have manifest separatist inclinations. In fact, the leader of NDPVF, Alhaji M.A. Dokubo, and his comrades have in the past made public appearances in full gear, complete with AK 47s, pistols and ammunition. It is noteworthy that the leaders of NDPVF and MASSOB had been on trial for, inter alia, treason. Relevant cases include Boro $v$ Republic [1966] 1 All NLR 266 and Enahoro $v R$ [1965] 1 All NLR 125.The gist of the offence is the levying of war against the State in order to intimidate or overawe the President or the Governor of a State.

The government of President Yar'Adua initiated an amnesty programme which seemed to cause a reduction in the hitherto frequent cases of ethic militia activities. Indeed, the threat is perennially present- for example, in reaction to the conviction of Henry Okah by a South African court for masterminding the Independence Day October 12010 bombing in Abuja, MEND threatened to "sabotage oil installations and South African companies"(see 2013. This Day Newspaper, January 28, pp 8. http://www.thisdaylive. com/articles/fg-advises-mend-not-to-resort-to-violenceover-okah/137673/ accessed January 28, 2013). In any case, there are still several cases of kidnap, including high-profile ones like that of mother of the Minister of Finance (see http://www.bbc.co.uk/news/ world-africa-20725677 accessed January 20, 2014).

It would apparently be draconian to prosecute people simply because they dream up some ideas in their heads. However, as soon as people begin to carry out acts that are reasonably suggestive and evidential of their anti-social intentions or plans, the law should be able to intervene. Section 4 of the Criminal Code Act defines "attempt":

When a person intending to commit an
offence, begins to put his intention into
execution by means adapted to its
fulfilment, and manifests his intention by
some overt act, but does not fulfil his
intention to such an extent as to commit
the offence, he is said to attempt to
commit the offence.

It would be naïve to suppose that what amounts to an attempt in criminal law is always clear. In fact, the UK Law Commission when proposing the 1981 Criminal Attempts Act found that there is no "magic formula" in the determination of what may constitute an attempt and thus considered the proximity test broadly acceptable. Ormerod (2011: 412). Since the UK position as contained in section 1 of the Criminal Attempts Act 1981, requires the commission of an act which is "more than merely preparatory to the commission of the offence", it is important to consider an overhaul of the approach to attempt under Nigerian 
criminal law especially in the context of preventive action and terrorism. More so, the UK legal regime has since factored this "more than merely preparatory" approach in its terrorism laws, for example section 5 of the UK Terrorism Act 2006.

In Nigeria, there is a constant threat to use violence (see http://www.thisdaylive.com/articles/outrage-growsover-kuku-dokubos-threats/147047/ accessed January 10, 2014). The point, therefore, should be increased vigilance and stiffer penalties for possession of firearms which could be effected by readily inferring attempt to commit offences in cases where the circumstances permit conjecture to that effect. However, there is arguably a real risk of ineffectiveness if the legal regime does not consider the practicality of going beyond merely preparatory acts in determining what may constitute an attempt. Therefore, there must be a careful balancing act concerning proactiveness and practicality. Clearly, the Nigerian legal regime, in the context of criminal and terrorism laws, should be more robust with a view to controlling small arms.

\section{Police Vigilance and Powers of Preventive Action}

"Every police officer may interpose for the purpose of preventing, and shall to the best of his ability prevent, the commission of any offence". This is provided in section 53(1) of the Criminal Procedure Act. This section contains two provisions. The first is that the officer's timely interposition would prevent the would-be offender from putting his intention into actuality and at the same time saving the would-be victim from experiencing the traumatic effect of a criminal act. A contextual example is using small arms to cause harm or even cause death. The second is the indication that it is not enough for a police officer to merely interpose; that is to say, interposition not based on the best of his ability to prevent crime is worthless. It should, therefore, be shown that in the circumstances of the case the reasonable person would come to the conclusion that the police officer has done everything humanly possible to prevent the crime.

The court arguably missed an opportunity to practically and usefully define "the best of his ability" in $R v$ Okoye [1950] 19NLR 103. Also see generally, Otubu and Coker (2008). The court did not precisely state what should be the nature of a preventive action which would determine how in any given case a police officer would have discharged his statutory duty "to the best of his ability". It has, however, become glaring that what would amount to "the best of his ability" for the police should not be left completely to the winds of circumstance. This is especially so in relation to the need to control the proliferation of small arms. There is arguably a consensus that the Nigerian police have often been incompetent in discharging their duties. It has been postulated that since the police possess public powers and perform public duties, it stands to reason that prima facie any member of the public can compel them to do their work. The crucial point is that once a duty exists, the police are compellable to enforce it "either by action at the suit of the AttorneyGeneral or by the prerogative writ of mandamus". In Fawenhinmi v IGP [2002] 7NWLR (Pt 665) 522, the Court of Appeal stated:

The public duty of a Chief Officer of Police to take due measures for the purposes of enforcing the law is potentially enforceable by mandamus and it is open to a member of the general public to obtain such an order. However, a substantial margin of discretion will be conceded to the police as to the appropriate method of enforcement. The police thus retain very considerable freedom to formulate and implement policies and to decide what to do in a particular case without...the risk of judicial intervention. Other bodies with statutory responsibilities for the enforcement of law would appear to be much in the same position.

However, in Nigeria, the approach of applying for a prerogative writ of mandamus may appear simplistic in view of the reality that the question of locus standi is relevant and is a somewhat controversial legal technicality. This is probably why the court, aware of this reality, quickly added that a court does not make an order which it cannot enforce. See Fawenhinmi $v$ IGP [2002] 7NWLR (Pt 665) 523. Nevertheless, it is common knowledge that the police have at times been apparently very negligent, for instance, as regards a notorious armed robber in time past, Lawrence Anini. See generally State $v$ Anini and Ors (unreported) Charge No. RFT/13/1/87. In fact, in Anini's case, a Deputy Superintendent of Police was allegedly the supplier of arms.

As such, it has to be carefully considered to what extent it may be necessary to raise the subjective test of "the best of his ability" to a more practically objective test in the light of modern exigencies if progress is to be made in control of small arms in the context of crime prevention. 


\section{Powers of Entry and Search}

The right to private and family life as established under the Nigerian Constitution is not absolute. Section 45(1) of the 1999 Constitution (as amended) provides that the right to privacy may be abrogated by a law that is reasonably justifiable in the interest of defence, public safety, public order, morality and for protecting the right and freedom of other persons.

The concurrent powers of entry and search can only be granted by a warrant or by any other statutory authority where entry is granted other than by a warrant, search can only be conducted with the permission of the occupier of the premises. However, once a police officer is lawfully on the premises, such an officer can exercise any police powers including inquiries about crime and, if need be, make arrests. See sections 107-111 of the Criminal Procedure Act. Also, Ezefor v Okeke [2000] 7NWLR (Pt 665) 513 CA:

The conditions for issuing a search warrant deserve close attention. This is particularly so because a person who stockpiles small arms at home is most unlikely to permit a police officer to enter and search without a warrant. Section 107 of the Criminal Procedure Act provides that a search warrant can only be issued:

Where a magistrate is satisfied by information upon oath and in writing that there is reasonable ground for believing that there is, in the state any building, ship, carriage, receptacle or place

a) Anything upon or in respect of which any offence has been or is suspected to have been committed, or

b) Anything which there is reasonable ground for believing will afford evidence to the commission of any offence, or

c) Anything which there is reasonable ground for believing is intended to be used for the purpose of committing any offence.

Totor $v$ Aweh [2000] 2NWLR (Pt 644) 309 CA is also a useful authority on the exercise and limits to the power of arrest without warrant.

These conditions may be permissible for ordinary chattels. It is however submitted that as regards the proliferation of small arms, the conditions are out of step with modern realities. For an unreasonably scrupulous and perhaps disinterested magistrate, there may never be sufficient reasons to issue a warrant to say, enter and search a house believed to contain a number of arms because perhaps "...there is (no) ground for believing (they are) intended to be used for the purpose of committing any offence" as provided in section 107(1)(c) of the Criminal Procedure Act. However, there are some cases where people have been found to stockpile arms. Some years ago, a State legislator was arrested and charged with eleven others for allegedly stockpiling arms and ammunition (see 2005. Vanguard, May 20, 2005, p 1).

If the Criminal Procedure Act has some perceived defects in the light of the need to have pro-active action to discourage the proliferation of small arms, then the Police Act gives cause for more concern. An example would serve. Under section 28(1) of the Police Act, the power of a superior police officer to authorise entry and search, unlike that of a magistrate under the Criminal Procedure Act which is far more comprehensive, is limited to stolen goods. It follows, therefore, that a superior police officer has no power to authorise entry and search of a private place for anything in connection with any crime, with the exception of the offence of stealing. Amadi (2000: 148). In the light of the aforementioned inadequacies, it would appear to be tantamount to running around in circles when the police have a duty to investigate crime properly. In Aigbadon $v$ State [2000] 7 NWLR (Pt 666) 686, the Supreme Court lamented that the police investigation left much to be desired. Uwais CJN observed that "any defence put up by an accused person whether stupid or spurious must be investigated thoroughly in order to render it false or unlikely".

\section{Powers to Stop, Inspect and Detain Vehicles}

Generally, under the Nigerian criminal justice system, the police have no powers merely to stop a citizen, without first effecting his arrest for the purpose of searching him. It is after arrest that the power of search is normally exercised. In Okeji v Olokoba [2000] 4NWLR (Pt 654) 513, the Court of Appeal stated, per Oduyemi, J.C.A:

I know of no law which empowers the police to detain a motor vehicle in such a circumstance particularly when it was not alleged that the vehicle had been used for the purpose of committing a crime-on the contrary the vehicle in this case was the victim of alleged criminal acts by the defendants...it was always open to the 
respondent to have applied to the police for the release of the motorcycle even before the criminal trial- upon an undertaking to produce the motorcycle as well as the replaced damaged parts, if required in evidence at the trials.

The routine stops at checkpoints in public highways appear to find root in section 29 of the Police Act which gives power to "detain and search any person when he reasonably suspected of having in his possession or conveying in any manner anything which he has reason to believe or has been stolen or otherwise unlawfully obtained." The alternative would be to arrest him under section 10 of the Criminal Procedure Act and proceed to search him under section 6(1) of the same Act.

In any case, there have been recent efforts to apparently get the police specifically more involved in traffic offences. This is arguably the case in Lagos State with respect to the latest law concerning road traffic. Section 8(2) and (3) of the Lagos State Road Traffic Law (the Lagos State Road Traffic Law 2012 repeals the Road Traffic Law Chapter R10, Vol. 7, Laws of Lagos State 2003 as amended) provide that complaints of "stationary or abandoned vehicles" may be made to the police or the traffic authorities. It does appear however that the Lagos State government would generally have no legal basis to give more powers to the police, and the police may not justifiably exercise such ostensible powers except they can be linked to a reasonable suspicion of committing crime. The police derive powers from the Police Act which is a federal legislation- and this remains within the exclusive domain of the federal legislature. From another perspective, there are other provisions which suggest that section 8 may be an overambitious anchorage on the general powers to prevent crimes as contained in the Police Act. Section 4 of the Police Act provides that "the police shall be employed for the prevention and detection of crime, the apprehension of offenders, the preservation of law and order, the protection of life and property and the due enforcement of all laws and regulations with which they are directly charged, and shall perform such military duties within or without Nigeria as may be required by them by, or under the authority of, this or any other Act." For example, section 22(1) of the Road Traffic Law also provides that a police officer or traffic officer "may arrest without warrant a driver of a motor vehicle on a highway who in his view commits an offence under sections 20,21 or 23 unless the driver either produces his licence to drive or produces his licence to drive or produces other evidence of his identity acceptable to the Police". Sections 20, 21 and 23 generally concern reckless driving, driving under the influence, and dealing fraudulently with an identification mark respectively. Section 28 also provides that a police officer or traffic officer may arrest without warrant "any person who commits in his view...or whom he reasonably suspects of having committed, an offence under this Law...". Thus, whilst the Road Traffic Law may have rough edges concerning vehicles and police powers, they nonetheless even if post-haste, seem to factor in the realities of transportation of small arms as vehicles clearly remain the most dominant form of transportation on land.

It might appear easy to observe that such provisions are helpful in checking proliferation of small arms but one may think differently upon realising that reasonable suspicion must be something more than imagination or conjecture. It must be that of a reasonable person. If that is pushed to its practically logical conclusion, it may be inevitable to consider cobweb justice. In any case, beyond the questionable drafting of the Road Traffic Law as it contains police powers, the Police Act itself (particularly sections 4 and 29) contains general powers for the police as it concerns transportation of small arms by vehicles. Indeed, the question is hardly whether the Nigerian police have the powers to be involved in traffic offences or even demand for particulars of vehicles or drivers' licences; the practical point is that it is a waste of very scarce police resources to engage in anything less than seriously combating crime especially when there are other traffic officers and the Federal Road Safety Corps. A similar argument has been made elsewhere. See Amadi, (2000: 166). Amadi further argued based on some other traffic law that such traffic legal provisions "become meaningless if they are to be overridden by provisions of the Criminal Procedure Act and the Police Act". However, it is contended, as can be distilled from earlier analysis that the drafting of the relevant traffic laws has been quite naïve as federal legislations on the subject ought to be factored in as they are prima facie and substantively, of federal application-it is more of learning not to put the cart before the horse.

Clearly, it can be distilled from the foregoing analysis that the myriad of semantics concerning various meanings on the same issue is not helpful. Clearly, there is a need for a special and compact legislation on the subject matter. 


\section{ADDRESSING CAUSES RATHER THAN EFFECTS}

Nigeria has actively participated in a number of policies which have been implemented internationally. In 2001, the Nigerian government established a National Committee on Small Arms and Light Weapons, co-sponsored the African Conference on the Implementation of Action in 2002, and adopted an African Common Position to review the UN Programme of Action to Prevent, Combat and Eradicate the Illicit Trade in Small Arms and Light Weapons in All its Aspects (UNPoA) in 2006. In the same year, Nigeria also adopted the ECOWAS Convention on Small Arms and Light Weapons, their Ammunition and other Related Materials-it stipulates strict controls on the transfer, manufacture, possession and security of small arms and light weapons. In 2007, Nigeria voted to begin negotiations with a view to attaining a legally binding Arms Trade Treaty. Although Nigeria was the first African country to ratify the Arms Trade Treaty in 2013, thus "indicating its willingness to join the global society in ensuring strict control of the international trade in conventional arms" (see https://www.amnesty. org/en/news/nigeria-becomes-first-african-nation-ratifyarms-trade-treaty-2013-08-14 accessed January 13, 2014), practical steps to implement such policies need to be taken in the domestic context. Perhaps, one of the boldest hard law efforts was the signing and ratification in 2006 of the United Nations Firearms Protocol against the Illicit Manufacturing of and Trafficking in Firearms, their Parts and Componentssupplementing the UN Convention against Transnational Organised Crime of 2001 (see http://treaties. un.org/Pages/ViewDetails.aspx?src=TREATY\&mtdsg no $=$ XVIII-12-c\&chapter $=18 \& l a n g=$ en accessed January 12, 2014). However, even further participation probably needs to be explored as the Wassenaar Arrangement on Export Controls and Conventional Arms and DualUse Goods and Technologies does not list Nigeria as a Participating State.

Nevertheless, as a result of all the efforts made at the governmental and policy levels, rather than in spite of them, there must be a corresponding line of practical action on the ground (Ryan, 2012). Although there is a National Taskforce to Combat Illegal Importation and Smuggling of Goods, Ammunition and Light Weapons (see http://natforce-ng.org/news-lagos\%20operations. $\mathrm{htm}$ accessed January 12, 2014), it is contended that it fits into the broad conventional or traditional typology of tackling the issue as it is apparently combative and confrontational.
Tackling the proliferation of small arms, as this article has attempted to show so far, is also a very practical issue. Indeed, Ryan (2012) made the point pungently:

Tougher measures to curb illicit weapons
such as tightly controlling exports and
collecting illicit arms are important -but
must be seen as only part of the solution.
We should also address the reasons why
guns end up in the hands of civilians.
Experience shows that national measures
to control arms need to be twinned with
local action to address the demand for
weapons.

In addition to the specific legislative loopholes already examined, it is thus necessary to summarise some of the more practical reasons "why guns end up in the hands of civilians":

(1) Small arms in Nigeria can be alarmingly cheap to obtain. For example in 2005, a new AK-47 (with two magazines) reportedly cost US $\$ 1,700$ in the delta. In the oil-rich town of Warri, youths have reportedly hawked pistols for as low as \$200 to $\$ 400$. Indeed, when there is a state of oversupply, it can be as cheap as $\$ 100$ (Vines, 2005: 358). This is consistent with a 2012 report. In Nigeria, the AK-47 gun costs between $\$ 180$ or about $\mathrm{N} 28,800$ and $\$ 200$, about N32,600 (see http://www.tellng.com/index.php?option=com_k2 \&view=item\&id=1786:how-illegal-arms-threatennigeria\%E2\%80\%99s-unity accessed January $13,2014)$.

(2) Small arms are plentiful in supply for reasons which include those already discussed. It should be added that Nigerian ports are still significantly porous. As recently as 2010, an Iranian was charged in a Nigerian court for conspiring to import and importing 13 20-feet containers loaded with assorted calibers of prohibited firearms" after the weapons had been seized at the Lagos port (see (http://www.spacewar.com/ reports/Nigerian_court_charges_Iranian_over_ar ms_cache_999.html accessed January 29, 2014). Porous ports encourage smuggling (Ojudu: 2004) through the waterways, so such loopholes must be plugged with efficient maritime security agencies. Clearly, better security at the ports would in turn, cause gun scarcity which would in turn arguably 
automatically cause an astronomical increase in price for those available.

(3) Since small arms are easily concealed and portable, and would indeed be likely carried about, every person carrying a gun on their person ought also to carry on their person a valid licence or a valid arms acquisition certificate to use or transport such arms.

(4) The spate of crime has often and persuasively been tied to Nigeria's economic adversity. Just as ex-service men felt impelled to use guns to get food after the Nigerian Civil War, people will do almost anything to survive as survival is the first law of nature.

(5) There cannot be too much emphasis on the need for a restructuring and overhaul of the Nigerian Police. Since the time of the notorious armed robber Lawrence Anini (see generally, State $v$ Anini \& Ors (unreported) Charge No. $\mathrm{RFT} / 13 / 1 / 87$, in which case a Deputy Superintendent of Police was Anini's arms supplier) or perhaps even before, the Nigeria Police Force has been in dire need of comprehensive overhaul. As regards efficiency, they are also in need of structural and tactical reform to suit the modern complexities of the proliferation of small arms (Atta, 1997: 27).

(6) The definition of firearms under the Firearms Act is quite unwieldy, which fact has contributed to the proliferation of small arms. There is a need for the law to give special attention to small arms, with a view to ensuring efficiency.

(7) It is retrogressive not to have dynamic laws which reflect in amendments as may be necessary. Such amendments should start from the definition of small arms and factor in all the contemporary intricacies of small arms as well as the varied threats by different sects and religious fundamentalist groups.

(8) Whilst it is conceded (but hardly stands to reason) that cases on small arms hardly come up, those which come up should be exploited to limits to make the corpus juris richer, more useful, and more comprehensive. It is obviously naïve to adopt everything British simply because of the Nigerian legal ancestry, thus any foreign law should be carefully considered and compared with Nigerian peculiarities. However, the reality is that jurisdictions which have dynamic laws are likely to have some good policies to offer. Nigeria is obviously not prepared for the American approach which is apparently one of the most liberal in the world whilst the UK approach has been described, and rightly too, as "among the strictest in the world". Interestingly, the UK and US gun legislations contrast but may be traced back to the same source-the 1689 Bill of Rights where the right to bear arms was guaranteed (see http://news.bbc. co.uk/2/hi/uk_news/7056245.stm accessed January 16, 2014). However, the American approach may also be differentiated on the basis of how it fought for freedom, which culminated in the American Declaration of Independence in 1776. As such Amendment II of the US Constitution American Constitution specifically provides for "A well regulated militia, being necessary to the security of a free State, the right of the people to keep and bear Arms, shall not be infringed." Also see Amendment XIV.

(9) It stands to reason that if countries which do not have as many cases of violence or casualties arising from the abuse and proliferation of small arms are relatively proactive, Nigeria really has no justification for legislative complacency.

(10) The scattered and sometimes conflicting nature of various statutes on the same subject matter, among other reasons stated above, bring to limelight the need for a comprehensive, detailed and compact legislation on small arms.

\section{CONCLUSION}

There must be increased attention given to nonconfrontational means of controlling proliferation, which is perhaps just another way of saying that practical preventive measures should be taken. The need for economic empowerment to reasonably reduce the urge to engage in illegal activities for survival is increasingly gaining momentum. The point has been made with respect to other issues of national concern like economic and financial crimes (Asogwah and Okoli, 2008: 241) and should be applied in controlling the proliferation of small arms. According to the National Bureau of Statistics, more than half of the Nigerian youth are reported to be unemployed (see http://m.news24.com/nigeria/National/News/54-percent-of-Nigerian-youth-unemployed-official-20131218 accessed January 23, 2014) and even where there is 
employment, it is a fact that minimum wage increases are not proportional to increases in prices (Fapohunda et al. 2012: 20). However, a corollary at the core of preventive measures is the need for realistic and modern provisions, especially with respect to fundamentals like definitions, movement of arms, police powers (which obviously permeate most of the issues raised) and establishing a proper nexus between crime and punishment.

It is at the level of enforcement that Nigerian laws tend to be at their weakest. However good the legislation (even though this is hardly the case in Nigeria), there is no functional use of enacting or adopting a law if best efforts will not be applied to enforce it. The enforcement of Nigerian legislation, especially on small arms, is at its low watermark, partly because the Nigeria Police Force as presently constituted, is paradoxically too cumbersome for effective administration, and inadequate in number for internal security responsibilities. This should be urgently considered, especially in the light of the reality that the Nigerian government has, perhaps for persuasive reasons not been forthcoming on the establishment of State Police. The debate as to whether the establishment of State Police is not viable due to the ethnic, religious and political divides that tend to be emphasised, is a matter for some other scholarly inquiry. In any case, it is the existence of compact but compartmentalised, well-equipped and semi-autonomous police formations that would help to arrest the illegal owners and bearers of small arms, identify their sponsors and bring all of them to justice.

\section{ACKNOWLEDGEMENT}

Pontian N. Okoli LL.M (Dundee), LL.B (Nig.), BL, is a Barrister and Solicitor of the Nigerian Supreme Court. $\mathrm{He}$ is currently engaged in advanced legal research at the School of Law, University of Dundee. Special thanks to Professor Frank Asogwah for accepting to supervise the initial project in 2006 when the idea seemed a bit avant-garde in Nigeria. Also, thanks to Gomiluk Otokwala, Onyedi Wingate and the anonymous reviewers for their comments on the draft. All errors and omissions remain mine.

\section{REFERENCES}

\section{Statutes}

Criminal Code Act of 1916 Chapter C38, LFN 2004

Criminal Procedure Act of 1945 Chapter C41, LFN 2004

Economic and Financial Crimes Commission (Establishment) Act 2004
Firearms Act of 1958 Chapter F28, LFN, 2004

Firearms Regulations of 1958 Chapter F28, LFN, 2004

Robbery and Firearms (Special Provisions Act) of 1984, Chapter R11, LFN 2004

Firearms Law (Guidance to the Police 2002) UK

Firearms (Amendment) (No. 2) Act of 1997 UK

Lagos State Road Traffic Law 2012

Police Act of 1943(Subsidiary Legislation), Chapter P19, LFN 2004

United Nations Firearms Protocol against the Illicit Manufacturing of and Trafficking in Firearms, their Parts and Components (supplementing the UN Convention against Transnational Organised Crime of 2001).

Violent Act Reduction Act 2006 UK

\section{Cases}

Aigbadon v State [2000] 7 NWLR (Pt 666) 686

Boro $v$ Republic [1966] 1 All NLR 266

Cafferata $v$ Wilson [1936] 3 All ER 149

Debbie v The State S.C 103/2005, delivered on 9 March 2007

Enahoro $v$ R [1965] 1 All NLR 125

Ezefor v Okeke [2000] 7NWLR (Pt 665) 513

Fawenhinmi v IGP [2002] 7NWLR (Pt 665) 522

Grace v DPP (1989) Crim. LR 365

Ikemson \& Ors $v$ State [1989] 3NWLR (Pt 110) 455 at 477

Moore v Gooderham [1960] 3 All E.R. 575

Nwachukwu v State [1985] 3NWLR (Pt 11) 218 at 225

Nwachukwu $v$ State [1986] 2NWLR (Pt 25) 765

Okeji v Olokoba [2000] 4NWLR (Pt 654) 513

Olatunji v State [2003] 14 NWLR (Pt. 839) 138 at pp 165-166

$R v$ Okoye [1950] 19NLR 103

$R v$ Singh (1989) Crim. L.R. 724

$R v$ Thorpe [1987] 85 Cr. App. Rep. 107

State $v$ Anini and Ors (unreported) Charge No. RFT/13/1/87

Tanko $v$ State [2009] 4NWLR (Pt 1131) 430 at 453

The Queen v Nwaogwugwu [1962] 1All NLR 294

Totor v Aweh [2000] 2NWLR (Pt 644) 309

\section{Books and Journal Articles}

Adinkrah, KO. 1986. Arresting armed robbery with arms: the case for freer access to guns in Nigeria. The Nigerian Law Journal. 13 (1): 71.

Alemika, Etannibi EO. and Chukwuma, Innocent C. (eds). 2004 Crime and Policing in Nigeria: Challenges and Options, Network on Police Reform in Nigeria. Retrieved from http://www.cleen.org/CRIME\%20AND\%20POLICING\%20IN $\% 20$ NIGERIA.pdf at p 10 (accessed January 19, 2014).

Amadi, GOS. 2000. Police Powers in Nigeria. Enugu: Afro-Obis Publications Ltd: 166, 148.

Asogwah, Frank I and Okoli, Pontian N. 2008. Economic Crimes and National Development Enugu: Institute for Development Studies: 241

Atta, Aliyu I. 1997. Service at Kam Salem House: My Years as Inspector-General of Police. Lagos: Blowsome Ventures Limited:96.

Fapohunda, Tinuke M., Atiku, Sulaiman Olusegun and Lawal, Ibrahim Olarenwaju. 2012. Minimum wage implementation in a post-recession economy: the Nigerian experience. European Scientific Journal 8(7): 20

Nwabueze, BO. 1993. Military Rule and Social Justice in Nigeria. Ibadan: Spectrum Law Publishing.

Ojudu, Babafemi. 2004. Gun Smuggling in the Niger Delta World Press Review, November 16. Retrieved from 
http://www.worldpress.org/cover7.htm (last accessed January 15, 2014).

Open Society Institute. 2010. Criminal Force: Torture, Abuse and Extrajudicial Killings by the Nigeria Police Force.) -a publication by the Network on Police Reform in Nigeria and the Open Society Institute. Retrieved from http://www.unhcr.org/refworld/pdfid/4cbc44742.pdf (accessed January 16, 2014).

Ormerod, David 2011 Smith and Hogan's Criminal Law, 13 ${ }^{\text {th }}$ ed. Oxford: Oxford University Press: 412.

Otubu, Akintunde Kabir and Coker, Sunday A. 2008. Police and Crime Prevention in Nigeria. Police Discretion: State Practices. Raadhakalyani, K. (ed) Amicus Books Icfai University Press India.

Oyebode, Akin. 2012. Legal Responses to the Boko Haram Challenge: An Assessment of Nigeria's Terrorism (Prevention) Act, 2011. Paper delivered at the Oxford Round Table, held at Harris Manchester College, the University of Oxford, England, July 22-26.

Ryan, Jordan. 2012. As the UN's small arms review conference ends, what is needed to reduce violence? Retrieved from http://www.undp.org/content/undp/en/home/ourperspective/o urperspectivearticles/2012/09/10/as-the-un-s-small-armsreview-conference-ends-what-is-needed-to-reduce-violencejordan-ryan.html (accessed January 13, 2014).

Vines, Alex. 2005. Combating Light Weapons Proliferation in West Africa. International Affairs 81(2): 358, Retrieved from http://www.chathamhouse.org/sites/default/files/public/Intern ational\%20Affairs/2005/inta_454.pdf (accessed January 12, 2014).

http://dx.doi.org/10.1111/j.1468-2346.2005.00454.x

Wakil, B. National Arms Production Capacity of Nigeria. 2005. Retrieved from http://www.poa-iss.org/CASACountryProfile/ OtherDocument/61@InvRpt_Nigeria.pdf at p 54 (accessed January 29, 2013).

\section{Newspapers and Magazines}

2013. Sunday Sun. February 4 (Lagos), p1.

2005. The Guardian. June 23 (Lagos), p1.

2013. TELL Magazine. January 7 (Lagos), pp 50-51.

2013. This Day Newspaper. January 28 (Lagos), p 8.

2005. Vanguard. May 20, 2005 (Lagos), p 1.

2005. The Guardian. January 23 (Lagos), p 21.

2013. Sunday Sun. February 4 (Lagos), p1.

2005. The Guardian. June 23 (Lagos), p1.

\section{Websites}

mdtf.undp.org/document/download/4666 (accessed January 15, 2014).

http://www.dyfed-powys.police.uk/archive/documents/FirearmsLaw. pdf (accessed January 12, 2014).

http://www.cps.gov.uk/legal/d_to_g/firearms/ (accessed January 12, 2014).

http://www.un.org/events/smallarms2006/faq.html (accessed January 13, 2014). http://www.maginternational.org/news/reducing-the-threat-of-smallarms-and-light-weapons/ (accessed January 29, 2013).

http://www.bbc.co.uk/news/world-us-canada-20730717 (accessed January 15, 2014).

http://www.un.org/disarmament/convarms/SALW/ (accessed January 13 2014).

http://www.undp.org/content/undp/en/home/presscenter/articles/2012 /09/07/preventing-illegal-flow-of-guns-is-key-to-reducingpoverty-/ (accessed January 14 2014).

http://www.thenationonlineng.net/archive2/tblnews_Detail.php?id=19 206 (accessed January 16, 2014).

http://dailytimes.com.ng/article/police-interrogate-human-rights-chief (accessed January 28, 2013).

http://www.thisdaylive.com/articles/fg-advises-mend-not-to-resort-toviolence-over-okah/137673/.

http://www.bbc.co.uk/news/world-africa-20725677 January 20, 2014).

(accessed

http://www.foxnews.com/world/2012/04/16/nigeria-police-want-tointerrogate-rights-leader/ (accessed January 20, 2014).

http://www.thisdaylive.com/articles/outrage-grows-over-kukudokubos-threats/147047/ (accessed January 10, 2014).

http://www.poa-iss.org/CASACountryProfile/OtherDocument/61@Inv Rpt_Nigeria.pdf (accessed January 29, 2013).

http://treaties.un.org/Pages/ViewDetails.aspx?src=TREATY\&mtdsg no $=X V I I I-12-c \&$ chapter $=18 \&$ lang $=$ en (accessed January 12 , 2014).

http://natforce-ng.org/news-lagos\%20operations.htm (accessed January 12, 2014)

http://www.tellng.com/index.php?option=com_k2\&view=item\&id=178 6:how-illegal-arms-threaten-nigeria\%E2\%80\%99s-unity (accessed January 13, 2014).

http://m.news24.com/nigeria/National/News/54-per-cent-of-Nigerianyouth-unemployed-official-20131218 (accessed January 23, 2014).

http://www.spacewar.com/reports/Nigerian_court_charges_Iranian_o ver_arms_cache_999.html (accessed January 29, 2014).

http://www.bbc.co.uk/news/uk-england-humber-20611395 (accessed January 17, 2014).

http://www.unhcr.org/refworld/pdfid/4cbc44742.pdf

(accessed January 16, 2014).

http://www.cleen.org/CRIME\%20AND\%20POLICING\%20IN\%20NIG ERIA.pdf (accessed January 19, 2014).

http://www.nigeriapolice.org (accessed January 29, 2013).

http://www.thenationonlineng.net/archive2/tblnews_Detail.php?id=19 206 (accessed January 16, 2014).

http://news.bbc.co.uk/2/hi/uk_news/7056245.stm (accessed January 16, 2014).

http://m.news24.com/nigeria/National/News/54-per-cent-of-Nigerianyouth-unemployed-official-20131218 (accessed January 23, 2014).

https://www.google.co.uk/\#q=https:\%2F\%2Fwww.amnesty.org\%2Fe $\mathrm{n} \% 2 \mathrm{Fnews} \% 2 \mathrm{Fn}$ ngeria-becomes-first-african-nation-ratifya++rms-trade-treaty-2013-08-14 (accessed January 13, 2014).

Received on 08-12-2013

Accepted on 03-02-2014

Published on 10-03-2014

DOI: http://dx.doi.org/10.6000/1929-4409.2014.03.06

(C) 2014 Pontian Okoli; Licensee Lifescience Global.

This is an open access article licensed under the terms of the Creative Commons Attribution Non-Commercial License (http://creativecommons.org/licenses/by-nc/3.0/) which permits unrestricted, non-commercial use, distribution and reproduction in any medium, provided the work is properly cited. 